ACTA UNIVERSITATIS NICOLA I C P ER NICI

EKONOMIA XLIII nr 1 (2012)

Pierwsza wersja złożona 2 kwietnia 2012

ISSN

Końcowa wersja zaakceptowana 15 września 2012

2080-0339

\title{
Stawomir Mentzen*
}

\section{KOSZTY DŁUGU PUBLICZNEGO I BANKRUCTWA PAŃSTWA}

Z a r y s t r e ś c i. W pracy zestawiono wyniki badań empirycznych dotyczących wpływu wysokości długu publicznego, deficytu budżetowego i bankructwa państwa na gospodarkę. Otrzymane rezultaty wskazują, że nadmierne zadłużenie jest bardzo szkodliwe dla rozwoju gospodarczego, w przeciwieństwie do ogłoszenia bankructwa, które na ogół uzdrawia gospodarkę i jest początkiem wyjścia z kryzysu.

S ło w a k l u c z o w e : dług publiczny, niewypłacalność państwa, bankructwo.

\section{WSTĘP}

Wiele państw Unii Europejskiej boryka się obecnie z wysokim poziomem długu publicznego. Przykład problemów Grecji pokazał, że nadmierny poziom zadłużenia jest niezwykle groźny dla gospodarki, dlatego rządy powinny pilnować, aby dług nie przekraczał bezpiecznego poziomu. Zwiększanie się długu publicznego istotnie wpływa na najważniejsze wskaźniki gospodarcze, takie jak inflacja, wzrost gospodarczy czy oprocentowanie państwowych obligacji. $Z$ drugiej strony zadłużanie się czasem jest korzystne. Pozwala utrzymać stały poziom konsumpcji oraz finansować potrzebne inwestycje.

Drugą kwestia poruszoną w pracy są skutki bankructwa państwa dla gospodarki. Decyzja, czy próbować spłacić wysokie zadłużenie, czy też ogłosić

* Adres do korespondencji: Sławomir Mentzen, Uniwersytet Mikołaja Kopernika, WNEiZ, ul. Gagarina 13A, 87-100 Toruń, e-mail: smentzen@doktorant.umk.pl.

(C) 2012 Wydawnictwo Naukowe Uniwersytetu Mikołaja Kopernika. All rights reserved. http://www.aunc.ekonomia.umk.pl 
niewypłacalność, może mieć niezwykle ważne konsekwencje dla przyszłości gospodarki krajowej. $\mathrm{Z}$ jednej strony spłacanie bardzo wysokiego długu może doprowadzić do wieloletniej stagnacji gospodarczej wynikającej z nałożenia wysokich podatków niezbędnych do obsługi długu. Z drugiej strony odmowa spłaty zadłużenia może wiązać się $\mathrm{z}$ utratą przez państwo reputacji oraz problemami co do możliwości zaciagania długu w przyszłości.

Celem pracy jest prezentacja dotychczasowych wyników badań dotyczących konsekwencji zwiększania długu publicznego oraz bankructwa państwa. W sytuacji podobnej do tej, w której niedawno znalazła się Grecja, rządzący muszą wiedzieć, jakie skutki przyniesie ogłoszenie bankructwa, a jakie próba obsługi ogromnego długu lub nawet jego dalsze zwiększanie. Wiedza ta jest niezbędna do podjęcia racjonalnej decyzji dotyczącej przyszłości długu.

\section{WPŁYW ZADŁUŻENIA NA GOSPODARKE}

\subsection{WPŁYW ZADŁUŻENIA NA PKB I INFLACJĘ}

Najpoważniejszą konsekwencją wzrostu zadłużenia może być ograniczenie wzrostu gospodarczego i wzrost inflacji. Negatywny wpływ zadłużenia na wzrost gospodarczy został opisany w klasycznej pracy Barro (1979). Obsługa rosnącego długu publicznego wymaga zwiększenia podatków lub ograniczenia wydatków rządowych. Zarówno jedno, jak i drugie wiąże się ze zmniejszeniem wzrostu gospodarczego. W ciagu ostatnich trzech lat wielu autorów podjęło próby oszacowania zależności wzrostu PKB od wysokości długu publicznego.

Pierwsze badanie, będące dla kolejnych autorów punktem odniesienia, zostało opisane w pracy Reinhart, Rogoff (2010). Autorzy przeanalizowali dane dla 44 państw z ostatnich 200 lat. Dzięki temu otrzymali około 3700 rocznych obserwacji, tym cenniejszych, że zebranych w najróżniejszych systemach politycznych i różnych momentach dziejowych. Osobno dokonano analizy dla krajów rozwijających się i rozwiniętych, ponieważ te drugie dzięki wyższemu rozwojowi gospodarczemu mogą sobie pozwolić na finansowanie znacznie wyższego zadłużenia, dlatego dług będzie miał mniejszy wpływ na dynamikę ich gospodarek.

Autorzy policzyli średni i medianowy wzrost gospodarczy dla państw o zadłużeniu poniżej $30 \%$ PKB, w przedziałach pomiędzy 30 a $60 \%$ PKB, 60 a $90 \%$ PKB oraz powyżej $90 \%$ PKB. Okazało się, że w przypadku państw rozwiniętych gospodarczo wysokość wzrostu gospodarczego nie ma związku z wysokością relacji długu do PKB dla zadłużenia poniżej 90\% PKB. Po prze- 
kroczeniu tej granicy średni wzrost gospodarczy spada o około 4 punkty procentowe $\mathrm{w}$ stosunku do państw znajdujących się $\mathrm{w}$ przedziale o najniższym długu, a medianowy wzrost jest niższy o ponad $1 \%$. Badanie pokazało też, że nie obserwuje się równoczesnego wzrostu inflacji i zmniejszenia dynamiki PKB w wyniku pojawienia się wysokiego zadłużenia państwa.

W przypadku państw rozwijających się wyniki są podobne. Zauważalne zmniejszenie się wzrostu gospodarczego następuje dopiero po przekroczeniu granicy 90\% PKB. Spadek średniego wzrostu PKB wynosi ponad 3 p.p., a spadek medianowego wzrostu 1,5 p.p. Inaczej niż dla krajów rozwiniętych zachowuje się inflacja. Stale rośnie wraz ze wzrostem zadłużenia, jest o ponad 10 p.p. wyższa dla państw o zadłużeniu powyżej $90 \%$ niż dla tych o relacji długu do PKB poniżej 30\%.

Osobno przeanalizowano wpływ na wzrost gospodarczy zadłużenia zagranicznego, traktowanego jak suma zadłużenia zagranicznego publicznego i prywatnego. Ograniczenie dynamiki wzrostu gospodarczego można zaobserwować już po przekroczeniu granicy zadłużenie w wysokości $60 \%$ PKB. Średni wzrost gospodarczy zmniejsza się wtedy o ponad 2,5 p.p., a medianowy wzrost o 1 p.p. Gdy relacja zadłużenia zagranicznego do PKB przekracza $90 \%$, średni wzrost spada o kolejne 2,5 p.p. i staje się ujemny, medianowy wzrost PKB zmniejsza się o 1 p.p., a średnia inflacja rośnie o prawie 4 p.p.

Fucceri i Zdzienicka (2012, s. 736) w badaniu obejmującym 154 państwa w latach 1970-2008, korzystając z Uogólnionej Metody Momentów (GMM), otrzymali próg $70 \%$, po przekroczeniu którego wzrost gospodarczy redukuje się o 1,8 p.p. Niższe progi okazały się statystycznie nieistotne. Przekroczenie poziomu $90 \%$ powoduje spowolnienie wzrostu już o ponad 2 p.p., przy czym wyższy poziom długu nie prowadzi już do kolejnych negatywnych konsekwencji dla PKB.

Zadłużenie publiczne w wysokości 90\% PKB powoduje znaczące zmniejszenie wzrostu PKB również w pracy Checherity i Rothera (2010, s. 15). Autorzy zbadali 12 państw Unii Europejskiej w latach 1970-2010, również wykorzystując metodę GMM.

Kumar i Woo (2010, s. 5-6), badając 38 rozwiniętych i rozwijających się państw w latach 1970-2007, otrzymali spadek dynamiki PKB o 0,2 p.p. w wyniku wzrostu wysokości długu publicznego o każde 10 p.p. Po zmierzeniu osobno efektu dla krajów rozwijających się, okazały się one niewiele bardziej podatne na wzrost zadłużenia niż kraje rozwinięte. Ten sam spadek dynamiki PKB wywołany przyrostem długu publicznego otrzymali Caner i in. (2010, s. 11) w badaniu obejmującym kraje rozwijające się. Efekt istnieje po przekroczeniu przez dług publiczny progu 64\% PKB. Dla krajów rozwiniętych uzyskali wynik 0,17 p.p. po przekroczeniu $77 \%$ PKB. 
Misztal (2011a, s. 113) zbadał wpływ wysokości długu publicznego na wysokość wzrostu gospodarczego w krajach Unii Europejskiej. Wykorzystując metodę wektorowej autoregresji (VAR), otrzymał spadek dynamiki PKB w wysokości 0,3 p.p. na każde 10 p.p. wzrostu zadłużenia.

\subsection{WPŁYW ZADŁUŻENIA NA KOSZT DŁUGU}

Znacznie większa liczba publikacji dotyczy próby oszacowania związku pomiędzy wysokością długu publicznego i deficytu budżetowego a oprocentowaniem rządowych obligacji. Wyniki otrzymane przez wybranych badaczy zestawiono w tabeli 1 .

Tabela 1. Wzrost oprocentowania obligacji długoterminowych w b.p. wywołany wzrostem relacji długu lub deficytu do PKB o 1 p.p.

\begin{tabular}{|c|c|c|c|c|}
\hline \multirow[t]{2}{*}{ Badanie } & \multirow[t]{2}{*}{ Dane } & \multicolumn{2}{|c|}{$\begin{array}{c}\text { Wzrost oprocentowania } \\
\text { obligacji wywołany wzrostem }\end{array}$} & \multirow[t]{2}{*}{ Uwagi } \\
\hline & & długu & deficytu & \\
\hline Taylor, 1993 & G7 & & 30 & \\
\hline Ades i in., 2000 & $\begin{array}{c}15 \text { rozwijających } \\
\text { się państw }\end{array}$ & & 34 & \\
\hline Reinhart, Sack, 2000 & 19 OECD G7 & & 912 & \\
\hline Gale, Orszag, 2002 & USA & & 50 & \\
\hline Ardagna, 2004 & 16 OECD & 16 & & \\
\hline Engen, Hubbard, 2004 & USA & $2-3$ & $30-60$ & \\
\hline Chinn, Frankel, 2005 & $\begin{array}{c}\text { Niemcy, Francja, } \\
\text { Wielka Brytania } \\
\text { i Hiszpania }\end{array}$ & $5-8$ & & \\
\hline Dai, Philippon, 2006 & USA & & 35 & Jeśli wzrost trwa 3 lata \\
\hline $\begin{array}{l}\text { Ardagna, Casseli, } \\
\text { Lane, } 2007\end{array}$ & 16 OECD & & 10 & $\begin{array}{l}\text { Wpływ długu widoczny } \\
\text { dopiero przy ponadprze- } \\
\text { cięnym zadłużeniu }\end{array}$ \\
\hline Laubach, 2009 & USA & $3-4$ & 25 & \\
\hline Thomas, Wu, 2009 & USA & & $30-60$ & Jeśli wzrost ma trwać 5 lat \\
\hline Misztal, 2011 & UE & $1-13$ & & \\
\hline
\end{tabular}

Wzrost oprocentowania podano w punktach bazowych (b.p.).

Źródło: zestawienie własne na podstawie: Ades i in., 2000; Reinhart, Sack, 2000, s. 179; Gale, Orzsag, 2002, s. 13-16; Ardagna, 2004, s. 15-18; Engen, Hubbard, 2004, s. 26-30; Chinn, Frankel, 2005; Dai, Philippon, 2006, s. 40-42; Laubach, 2009, s. 10-13; Thomas, Wu, 2009; Misztal, 2011.

Mimo stosowania przez autorów różnych podejść do stawianego zagadnienia, otrzymane wyniki są w miarę spójne. Wzrost wysokości długu publicz- 
nego o 1 p.p. powoduje wzrost oprocentowania długoterminowego o około 5 b.p., wzrost deficytu o 1 p.p. skutkuje przyrostem oprocentowania długu średnio o 30 b.p.

Należy zwrócić uwagę, dlaczego koszt obsługi długu rośnie znacznie szybciej w wyniku wzrostu deficytu niż wskutek przyrostu długu. Jak wskazuje Laubach (2009), należy rozważyć dwa skrajne przypadki. Jeśli z jednej strony wartości w kolejnych latach relacji deficytu do PKB byłyby całkowicie nieskorelowane, to wzrost deficytu o 1 p.p. zwiększyłby poziom długu jako część PKB również o 1 p.p. W takim przypadku wzrost oprocentowania powinien być identyczny. Jeśli jednak założyć, że każda nowa wysokość deficytu będzie utrzymywana w przyszłości na nie mniejszym poziomie, wtedy całkowity wzrost relacji długi do PKB wyniesie $(g+1) / g$, gdzie $g$ jest wzrostem nominalnego PKB danego kraju. Dla przykładu, w ostatniej dekadzie polska gospodarka rosła nominalnie o $6,6 \%$ rocznie, czyli oddziaływanie wzrostu deficytu o 1 p.p. dla Polski byłoby 16 razy silniejsze niż wzrost długu o 1 p.p. przy założeniu, że większy deficyt jest utrzymywany permanentnie. Oczywiście każdy z tych dwóch skrajnych przypadków jest nierzeczywisty, faktycznie zaledwie część wzrostu deficytu utrzymuje się przez kilka lat, dlatego ostateczny wpływ wzrostu deficytu może rzeczywiście być około 10 razy większy niż wpływ zwiększenia się długu.

Inną wyraźną zależnością jest znacznie wyższy oczekiwany wzrost oprocentowania długu $\mathrm{w}$ badaniach dotyczących jednego kraju niż tych dotyczących grupy krajów. Dla przykładu Ardagna i in. (2007), badając wzrost oprocentowania 10-letnich obligacji rządowych 16 krajów należących do OECD, otrzymali wzrost oprocentowania w wysokości 10 b.p. za każdy 1 p.p. wzrostu deficytu. Tymczasem stosujący podobną metodologię i ten sam wskaźnik fiskalny Dai i Philippon (2006) uzyskali dla Stanów Zjednoczonych wzrost o 35 b.p. Przyczyną tego może być obciążenie danych dla poszczególnych krajów przez różnorodne instytucjonalne i strukturalne czynniki, które nie są ujęte w trakcie badań.

Wielu autorów (Bernoth i in., 2004; Ardagna i in., 2007) zwraca uwagę, że efekt zwiększenia się oprocentowania obligacji w wyniku wzrostu długu jest nieliniowy. Jest on wolniejszy w przypadku niskiego długu i przyspiesza wraz ze wzrostem zadłużenia. Wysokie zadłużenie państwa oznacza wyższe ryzyko utraty zdolności do regulowania należności oraz podnosi poziom inflacji, co zwiększa nominalne oprocentowanie. Pierwszy z wymienionych efektów w krajach rozwiniętych, należących do OECD, pojawia się dopiero po przekroczeniu przez dług poziomu $60 \%$ PKB (Ardagna i in., 2007). Oznacza to, że przy szacowaniu opisywanego efektu wzrostu oprocentowania obligacji należy brać pod uwagę również wyjściowy poziom zadłużenia. W dodatku gwałtowne 
zwiększenie się deficytu budżetowego może powodować nieproporcjonalnie większe, nieliniowe zmiany oprocentowania.

Procesy globalizacji ułatwiły dostępność do kapitału i do rynku długu, dzięki czemu pozwoliły na znaczne zadłużanie się rozwiniętych i rozwijających się krajów, przy zachowaniu niskiego oprocentowania długu. Jednym $\mathrm{z}$ efektów tego procesu jest fakt, że na wycenę obligacji duży wpływ mają czynniki zewnętrzne, takie jak światowy apetyt na ryzyko, ilość globalnych oszczędności czy aktualne preferencje światowego kapitału spekulacyjnego i inwestycyjnego (Baldacci, Kumar, 2010). Innym istotnym, a często pomijanym czynnikiem jest bankowa lub giełdowa orientacja rynku finansowego badanego państwa. Jak wskazuje Międzynarodowy Fundusz Walutowy (IMF, 2006), gospodarkom o wysokim poziomie oszczędności krajowych i systemie finansowania opartym na systemie bankowym łatwiej jest zaabsorbować wzrost podaży obligacji. Oba wymienione efekty oznaczają, że szeroko dyskutowane czynniki wewnętrzne, takie jak poziom zadłużenia, nie są jedynymi czynnikami określającymi poziom oprocentowania obligacji.

\subsection{SYTUACJA POLSKI}

W przypadku krajów rozwijających się groźne jest przekroczenie przez dług publiczny granicy $90 \%$ PKB oraz wartość zadłużenia zagranicznego przekraczająca $60 \%$ PKB. Oznacza to, że dla gospodarki Polski groźniejsze od długu publicznego, który obecnie wynosi $55 \%$ PKB, jest zadłużenie zagraniczne. Jego wysokość na koniec 2011 roku wyniosła 59\% i niebezpiecznie zbliżyła się do granicy $60 \%$, której przekroczenie wiąże się ze średnim spadkiem wzrostu gospodarczego o 2,5 p.p. ${ }^{1}$

Przy obecnym poziomie zadłużenia oraz planach stopniowego zmniejszania deficytu budżetowego nie należy spodziewać się gwałtownego wzrostu kosztów obsługi polskiego długu publicznego.

\section{WPŁYW BANKRUCTWA NA GOSPODARKE}

W przypadku gdy dłużnikiem jest przedsiębiorstwo lub osoba fizyczna, wierzyciel ma wiele możliwości odzyskania pieniędzy. Inaczej wygląda sytuacja, gdy dłużnikiem jest państwo. W takim przypadku dług nie ma żadnego zabezpieczenia i w razie niekontrolowanego bankructwa wierzyciele nie mają szans odzyskać nawet części swoich pieniędzy. Z drugiej strony, gdyby ogło-

\footnotetext{
1 www.stat.gov.pl
} 
szenie bankructwa przez rząd kończyło się tylko pozbyciem się długu, to następowałoby to znacznie częściej, niż zdarza się w rzeczywistości. Państwo ogłaszające niewypłacalność ponosi jednak pewne koszty. W literaturze wyróżnia się dwa główne rodzaje kosztów związanych z ogłoszeniem niewypłacalności. Pierwszym jest utrata reputacji, która wiąże się $\mathrm{z}$ wykluczeniem z rynków finansowych oraz konsekwencjami politycznymi względem rządzących. Drugim rodzajem kosztów jest możliwość utraty części majątku państwa na rzecz wierzycieli oraz pojawienie się sankcji ograniczających handel międzynarodowy. Trzecim, rzadziej opisywanym kosztem jest ryzyko załamania się krajowego sektora bankowego, w którego aktywach mogą znajdować się znaczne ilości instrumentów dłużnych bankrutującego państwa (De Paoli i in., 2006).

Oszacowanie kosztów bankructwa państwa jest $\mathrm{z}$ wielu powodów bardzo trudne. Przykładowo trudno odróżnić koszty bankructwa samego w sobie od kosztów związanej z bankructwem recesji. Problematyczne jest nawet określenie, czy to recesja jest przyczyną bankructwa, czy może to bankructwo powoduje recesję (Borensztein, Panizza, 2008b).

\subsection{WPŁYW BANKRUCTWA NA PKB}

Jednym ze skutków bankructwa państwa może być spadek dynamiki PKB. $\mathrm{W}$ tabeli 2 umieszczono ostatnie rezultaty badań w tym zakresie.

Tabela 2. Wpływ niewypłacalności państwa na PKB

\begin{tabular}{|l|c|}
\hline \multicolumn{1}{|c|}{ Badanie } & Spadek dynamiki PKB w okresie niewypłacalności \\
\hline Levy-Yeyati i Panizza, 2006 & 2,8 \\
Sturzenegger, 2006 & $0,2-2$ \\
Borensztein i Panizza, 2008b & 1,2 \\
\hline
\end{tabular}

Spadek dynamiki PKB podano w punktach procentowych.

Źródło: zestawienie własne na podstawie: Levy-Yeyati, Panizza, 2006, s. 9; Sturzenegger, Zettelmeyer, 2006; Borensztein, Panizza, 2008b, s. 8.

Okazuje się, że wpływ bankructwa na PKB jest dosyć istotny. Aby go w pełni ocenić, należy jednak zbadać kształtowanie się tego wpływu w czasie. Borensztein i Panizza (2008b) wykazali, że efekt spadku dynamiki PKB jest najsilniejszy w roku, w którym ogłoszono bankructwo, i wynosi wtedy 2,6 punktu procentowego. Z kolei Levy-Yeyati i Panizza (2006) pokazali, że ogłoszenie bankructwa nie powoduje kryzysu, lecz jest jego konsekwencją. Biorąc pod uwage skumulowany wzrost gospodarczy w przedziale 12 kwartałów 
przed ogłoszeniem bankructwa i po nim, autorzy wyciagnęli następujące wnioski. W wyniku bankructwa skumulowany wzrost gospodarczy z ujemnego staje się dodatni, a różnica pomiędzy stopą wzrostu przed bankructwem i po nim zwiększa się wraz z czasem. Może to oznaczać, że bankructwo państwa powoduje poprawienie sytuacji gospodarczej, prowadzi do jej uzdrowienia. Nadmierne zadłużenie może prowadzić do kryzysu gospodarczego, ale bankructwo kryzysu nie zwiększa, tylko pozwala z niego wyjść. Wyniki zawarte w tabeli 2 dowodzą raczej faktu, że do bankructwa dochodzi w trakcie złej sytuacji gospodarczej, niż że bankructwo powoduje pogorszenie się kondycji gospodarki.

Analizę wpływu bankructwa na PKB należy uzupełnić o skutki długoterminowe. Levy-Yeyati i Panizza (2006) otrzymali następujące wyniki. W 70\% przypadków dynamika PKB jest wyższa po ogłoszeniu niewypłacalności niż przed nią. Co więcej, w 50\% przypadków po ogłoszeniu niewypłacalności wzrost PKB jest wyższy niż średnia długoterminowa. Podobne wyniki uzyskano dla poziomu bezrobocia, które rośnie w trakcie trwania kryzysu i narastania długu, by zacząć maleć od razu po ogłoszeniu niewypłacalności państwa. Potwierdzają to wyniki otrzymane dla krótkiego terminu i świadczą o pozytywnym wpływie ogłoszenia niewypłacalności dla gospodarki krajowej.

\subsection{WPŁYW BANKRUCTWA NA REPUTACJĘ}

Bankructwo państwa ma wpływ nie tylko na aktualną kondycję gospodarczą państwa. Istotnym kosztem bankructwa jest utrata reputacji zarówno przez aktualnie rządzących polityków, jak i przez państwo jako całość. English (1996), analizując przypadki niewypłacalności w XIX wieku, doszedł do wniosku, że gdy nie ma możliwości nałożenia na dłużnika embarga handlowego, spłaca on swój dług tylko i wyłącznie z powodu troski o swoją reputację. $\mathrm{W}$ dodatku państwa niemające problemu ze spłatą zadłużenia mogą dzięki dobrej reputacji więcej i taniej się zadłużać. Takie same wnioski zawierają prace Worrala (1990), Atkesona (1991) oraz Amadora (2003).

Utrata reputacji, blokująca dostęp do światowych rynków finansowych i uniemożliwiająca tym samym zaciaganie długu w przyszłości, nie jest oczywiście wieczna. $\mathrm{W}$ dodatku inwestorzy nie biorą pod uwage jedynie historii spłacania zadłużenia przez państwo, w którego papiery dłużne chcą zainwestować. Gdy tylko państwo wdroży program naprawczy i zacznie spłacać swoje zobowiązania, może liczyć na ponowny dostęp do rynków finansowych. Przykładowo Borensztein i Panizza (2008b) zwracają uwage, że od lat trzydziestych do sześćdziesiątych XX wieku wszystkie państwa Ameryki Południowej nie miały możliwości pozyskiwania pieniędzy na rynkach międzyna- 
rodowych niezależnie od tego, czy wcześniej bankrutowały, czy też nie. Gelos i in. (2004) policzyli, że państwa bankrutujące w latach osiemdziesiątych XX wieku uzyskiwały dostęp do rynków finansowych średnio po czterech latach. W latach dziewięćdziesiątych XX wieku średnia była jeszcze mniejsza i wyniosła zaledwie cztery miesiące po ogłoszeniu niewypłacalności.

Tabela 3. Ogłoszenie niewypłacalności a dostęp do rynków finansowych w latach dziewięćdziesiątych

\begin{tabular}{|l|c|c|}
\hline Kraj & Rok ogłoszenia niewypłacalności & $\begin{array}{c}\text { Rok odzyskania dostępu } \\
\text { do rynków finansowych }\end{array}$ \\
\hline Algieria & 1991 & 1991 \\
Etiopia & 1991 & 1992 \\
Rosja & 1991 & 1992 \\
Filipiny & 1992 & 1992 \\
RPA & 1993 & 1993 \\
Wenezuela & 1995 & 1995 \\
Indonezja & 1998 & 1998 \\
Ukraina & 1998 & 1998 \\
Rosja & 1998 & 2000 \\
Ekwador & 1999 & 2000 \\
\hline
\end{tabular}

Źródło: Gelos i in., 2004.

Inną konsekwencja, aczkolwiek trudniejszą do zmierzenia, jest wzrost oprocentowania długu państwa, któremu zdarzyło się nie spłacić wcześniej swoich długów. Popularną metodą uchwycenia powyższej zależności jest badanie relacji pomiędzy wcześniejszą niewypłacalnością a credit ratingiem, od którego zależy oprocentowanie obligacji. Cantor i Packer (1996) zbudowali model zmian credit ratingu uwzględniający historię spłat długu, który wyjaśnia ponad $90 \%$ zmian oceny kredytowej. Okazuje się, że ogłoszenie niewypłacalności w ciaggu ostatnich dwudziestu lat zmniejsza ocenę kredytową o 2 noty. Borensztein i Panizza (2008b), analizując to samo zagadnienie, otrzymali spadek o 1,7 noty.

Istnieją również prace próbujące wykazać bezpośredni wpływ wcześniejszych bankructw na oprocentowanie długu. Lindert i Morton (1989), badając osobno poszczególne okresy XX wieku, doszli do wniosku, że przeważnie wcześniejsze problemy ze spłatą zadłużenia nie mają wpływu na wysokość odsetek. Jeżeli w którymś okresie taki wpływ istnieje, to dotyczy on wszystkich państw mających wcześniej problemy z długiem i jest konsekwencją światowej koniunktury gospodarczej i skłonności do ryzyka inwestorów. Analizując lata dziewięćdziesiąte XX wieku, do identycznych wniosków doszli 
Ades i in. (2000). Borensztein i Panizza (2008b) otrzymali statystycznie istotny wzrost kosztu długu jedynie w roku bezpośrednio następującym po bankructwie. Wyniki stwierdzające długoterminową zależność pomiędzy kosztem długu a wcześniejszymi bankructwami (Ozler, 1993; Flandreau, Zumer, 2004; Dell'Ariccia, 2002) dotyczą przeważnie lat przed drugą wojną światową. Może też wskazywać, że z biegiem lat inwestorzy zaczęli zwracać mniejszą uwagę na historię regulowania zobowiązań przez państwa.

Podsumowując, można zauważyć, że troska o utrzymanie reputacji jest w obecnych czasach przesadzona. Wyniki empiryczne pokazują, że inwestorzy szybko zapominają o bankructwach. Rządy państw, które dopiero co zbankrutowały, nie maja problemu $\mathrm{z}$ dostępem do światowych rynków finansowych, a te w dodatku nie każą sobie płacić więcej za ryzyko finansowania niedawnego bankruta.

\subsection{WPŁYW BANKRUCTWA NA HANDEL MIĘDZYNARODOWY}

Rose (2005) wyróżnia dwa powody, dla których bankructwo państwa miałoby zaszkodzić handlowi międzynarodowemu. Przede wszystkim wierzyciele mogą spróbować zniechęcić za pomocą wprowadzenia utrudnień w handlu zadłużone państwa do ogłoszenie niewypłacalności w przyszłości. Drugim powodem mogą być problemy z zaciąganiem przez firmy krótkoterminowych kredytów obrotowych, które stanowią podstawę finansowania handlu międzynarodowego.

Niewielu autorów próbowało oszacować wpływ bankructwa na handel międzynarodowy. Rose (2005) uzyskał długoterminowy spadek handlu pomiędzy bankrutem a wierzycielem w wysokości $8 \%$, utrzymujący się przez 15 lat. Borensztein i Panizza (2008a) wykazali, że bankructwo państwa jest szczególnie szkodliwe w zakresie handlu dla gospodarek opartych na eksporcie. Przy czym w przeciwieństwie do Rose'a (2005) stwierdzili, że efekt zmniejszenia się eksportu jest krótkoterminowy.

$\mathrm{Z}$ pewnością można stwierdzić, że bankructwo państwa prowadzi do zmniejszenia wielkości handlu międzynarodowego. Wysokość tego spadku oraz jego zasięg w czasie muszą być jeszcze dokładniej oszacowane. Na podstawie dotychczasowych badań nie można wyciagnąć jednoznacznych wniosków.

\section{PODSUMOWANIE}

Przedstawione wyniki sugerują, że z punktu gospodarki szkodliwe jest nadmierne zadłużanie państwa, a nie ogłoszenie bankructwa. Wysoki dług 
prowadzi do niskiego wzrostu gospodarczego i wysokiej inflacji, powoduje też wzrost kosztów obsługi zadłużenia. Bankructwo jest najprostszą drogą do pozbycia się wysokiego długu, zwłaszcza w świetle badań empirycznych pokazujących niewielki związek pomiędzy reputacją państwa a jego zdolnościami do przyszłego zadłużania się. Można wyciagnąć wniosek, że państwa mające problemy ze spłatą wysokiego zadłużenia nie powinny ryzykować długotrwałej recesji i obciążania społeczeństwa wysokimi podatkami, próbując spłacić dług. $Z$ tych samych przyczyn przyjmowanie pomocy międzynarodowej, mającej pomóc w spłacie zadłużenia, nie leży w interesie zadłużonego państwa. Optymalną decyzją rządu jest doprowadzenie do kontrolowanego bankructwa i pozbycie się w ten sposób długu.

\section{LITERATURA}

Ades A., Kaune F., Leme P., Masih R., Tenengauzer D. (2000), Introducing GS-ESS: A New Framework for Assessing Fair Value in Emerging Markets Hard-Currency Debt, „Global Economics Paper”, No. 45, Goldman Sachs, New York.

Amador M. (2003), A Political Economy Model of Sovereign Debt Repayment, Working Paper, Stanford University, http://sticerd.lse.ac.uk/dps/resm2003/amador.pdf (1.04.2012)

Ardagna S. (2004), Financial Markets' Behavior Around Episodes of Large Changes in the Fiscal Stance, ECB Working Series, No. 90, September.

Ardagna S., Caselli F., Lane T. (2007), Fiscal Discipline and the Cost of Public Debt Service: Some Estimates for OECD Countries, NBER Working Paper No. 10788.

Atkeson A. (1991), International Lending with Moral Hazard and Risk of Repudation, „Econometrica”, 59 (4).

Baldacci E., Kumar M. (2010), Fiscal Deficit, Public Debt, and Sovereign Bond Yields, IMF Working Paper.

Barro R. (1979), On the Determination of the Public Debt, „The Journal of Political Economy”, 87 (5), part 1, 940-971.

Bernoth K., von Hagen J., Schuknecht L. (2004), Sovereign Risk Premia in the European Government Bond Market, ECB Working Paper No. 369.

Borensztein E., Panizza U. (2008a), Do Sovereign Defaults Hurt Exporters?, Springer Science.

Borensztein E., Panizza U. (2008b), The Costs of Sovereign Default, IMF Working Paper.

Caner M., Grennes T., Koehler-Geib F. (2010), Finding the Tipping Point - When Sovereign Debt Turns Bad, The World Bank Latin America and the Carribean Region Economic Policy Sector, July.

Cantor R., Packer F. (1996), Determinants and Impact of Sovereign Credit Ratings, „Economic Policy Review”, Federal Reserve Bank of New York, 2 (2), October, $37-53$. 
Checherita C., Rother P. (2010), The Impact of High and Growing Government Debt on Economic Growth, ECB Working Paper, No. 1237.

Chinn M., Frankel J. (2005), The Euro Area and World Interest Rates, Department of Economics, University of California, Santa Cruz Working Paper Series, No. 1031.

Dai Q., Philippon T. (2006), Fiscal Policy and the Term Structure of Interest Rates. NBER Working Paper, No. 11754.

Díaz-Alejandro C. (1983), Stories of the 1930s for the 1980s, „Financial Policies and the World Capital Market: The Problem of Latin American Countries”, Chicago: University of Chicago Press.

De Paoli B., Hoggart G., Saporta V. (2006), Costs of Sovereign Default, Financial Stability Paper No. 1, Bank of England.

Dell'Ariccia G., Schnabel I., Zettelmeyer J. (2002), Moral Hazard and International Crisis Lending: A Test, IMF Working Paper, 02/181.

Engen E., Hubbard R. (2004), Federal Government Debt and Interest Rates, NBER Working Paper, No. 1068.

English W. (1996), Understanding the Costs of Sovereign Default: American State Debts in the 1840s, American Economic Review, 86 (1), 259-75.

Flandreau M., Zumer F. (2004), The Making of Global Finance 1880-1913, OECD Development Center Research Monograph.

Furceri D., Zdzienicka A., (2012), How costly are debt crises?, „Journal of International Money and Finance", 31.

Gale W., Orzsag P. (2002), The Economic Effects of Long-Term Fiscal Discipline, Tax Policy Center Discussion Paper, December.

Gelos R., Ratna S., Sandleris G. (2004), Sovereign Borrowing by Developing Countries: What Determines Market Access?, IMF Working Paper, 04/221.

Haugh D., Ollivaud P., Turner D. (2009), What Drives Sovereign Risk Premiums? An Analysis of Recent Evidence from the Euro Area, Economics Department Working Paper, No. 718.

International Monetary Fund (2006), World Economic Outlook, Financial Systems and Economic Cycles, Washington: International Monetary Fund.

Laubach T. (2009), New Evidence on the Interest Rate Effects of Budget Deficits and Debt, Finance and Economics Discussion Series Divisions of Research \& Statistics and Monetary Affairs Federal Reserve Board, Washington, D.C.

Levy-Yeyati E., Panizza U. (2006), The Elusive Costs Of Sovereign Defaults, Inter-American Development Bank Working Paper.

Lindert P., Morton P. (1989), How Sovereign Debt Has Worked, „Developing Country Debt and Economic Performance", NBER, 39-106.

Kumar M., Woo J. (2010), Public Debt and Growth, IMF.

Misztal P. (2011a), Dlug publiczny $i$ wzrost gospodarczy w krajach czlonkowskich Unii Europejskiej, „Polityki Europejskie. Finanse i Marketing”, 54 (4).

Misztal P. (2011b), Oddziaływanie długu publicznego na zmiany dlugoterminowych stóp procentowych $w$ krajach członkowskich strefy euro $w$ okresie 2003-2010, „Oeconomia Copernicana”, nr 3. 
Ozler S. (1993), Have Commercial Banks Ignored History?, „American Economic Review", 83 (3), 608-620.

Reinhart C., Rogoff K. (2010), Growth in a Time of Debt, „American Economic Review Papers and Proceedings".

Reinhart V., Sack B. (2000), The Economic Consequences of Disappearing Government Debt, Brookings Papers on Economic Activity: 2, Brookings Institution, Washington.

Rose A. (2005), One Reason Countries Pay Their Debts: Renegotiation and International Trade, „Journal of Development Economics”, 77 (1), 189-206.

Sturzenegger, F., Zettelmeyer J. (2006), Debt Defaults and Lessons from a Decade of Crises Cambridge, Massachusetts: MIT Press.

Taylor J. (1993), Macroeconomic Policy in a World Economy, New York: W. W. Norton \& Company

Thomas L., Wu D. (2009), Long-term Interest Rates and Future Expected Budget Deficits: Evidence from the Term Structure, „Applied Economics Letters”, 16.

Worrall T. (1990), Debt with potential repudiation, „European Economic Review”, 34 (5).

\section{THE COSTS OF SOVEREIGN DEBT AND DEFAULT}

A b s tract. This paper summarizes the results of empirical studies on the effects of sovereign debt, deficit and default on the economy. The obtained results shows that excessive debt and deficit are very harmful for economic growth, as opposed to default, which tend to heal the economy and usually is the end of crisis.

K e y w ord s : sovereign debt, default, growth. 